\title{
PIK3CA NM_006218.1:C.1624G>A
}

National Cancer Institute

\section{Source}

National Cancer Institute. PIK3CA NM 006218.1:C.1624G>A. NCI Thesaurus. Code C98475.

A nucleotide substitution at position 1624 of the coding sequence of the PIK3CA gene where guanine has been mutated to adenine. 